\title{
Pengaruh Turnover Intention dan Teknologi Informasi terhadap Kepuasan Kerja pada Masa Pandemi Covid-19
}

\author{
Ayu Lestari ${ }^{1)}$, Wani Fitriah ${ }^{2)}$, Anggreany Hustia ${ }^{3)}$ \\ 1), 2), 3) Universitas Muhammadiyah Palembang \\ Email:ayuu088@gmail.com ${ }^{1)}$,wanifitriah61@gmail.com ${ }^{2)}$,reanyhustia1012@gmail.com ${ }^{3)}$
}

\begin{abstract}
This research was conducted to determine the effect of turnover intention and information technology on job satisfaction during the covid-19 pandemic in PT. Kereta Api Indonesia (Persero) Divisi Regional III Palembang. The population of 116 employees and a sample of 90 respondents were calculated using slovin formula with 5\% error rate, sampling techniques using proportionate stratified random sampling. The data used is primary data. Methods of collected data through questionnaires. Analysis techniques use multiple linear regressions, F-tests, $t$ tests and determination tests. The results of regression tests and F-tests showed there was an influence of turnover intention and information technology on job satisfaction during the covid-19 outbreak. The results of the t test showed there was an influence of turnover intention on job satisfaction, and there was an influence of information technology on job satisfaction. And the results of the determination test showed variable turnover intention and information technology was able to contribute to job satisfaction.
\end{abstract}

Keywords: Turnover Intention, Information Technology, Job Satisfaction

\begin{abstract}
Abstrak
Penelitian ini dilakukan untuk mengetahui pengaruh turnover intention dan teknologi informasi terhadap kepuasan kerja pada masa pandemi covid-19 di PT. Kereta Api Indonesia (Persero) Divisi Regional III Palembang. Populasi berjumlah 116 orang karyawan dan sampel sebanyak 90 orang responden yang dihitung menggunakan rumus Slovin dengan tingkat kesalahan 5\%, dan teknik pengambilan sampel menggunakan proportionate stratified random sampling. Data yang digunakan adalah data primer. Metode pengumpulan data melalui kuesioner. Teknik analisis menggunakan regresi linier berganda, uji F, uji t dan uji determinasi. Hasil pengujian regresi dan uji $\mathrm{F}$ menunjukkan ada pengaruh turnover intention dan teknologi informasi terhadap kepuasan kerja pada masa pendemi covid-19. Hasil uji t menunjukkan ada pengaruh turnover intention terhadap kepuasan kerja, dan ada pengaruh teknologi informasi terhadap kepuasan kerja. Dan Hasil uji determinasi menunjukkan variabel turnover intention dan teknologi informasi mampu berkontribusi terhadap kepuasan kerja.
\end{abstract}

Kata Kunci: Turnover Intention, Teknologi Informasi, Kepuasan Kerja

\section{Pendahuluan}

PT. Kereta Api Indonesia (Persero) Divisi Regional III Palembang salah satunya yang bergerak dibidang jasa transportasi di Indonesia. PT. Kereta Api Indonesia (Persero) Divisi Regional III Palembang selalu berusaha terus melakukan peningkatan kualitas dalam pelayanannya terlebih di Era Revolusi Industri 4.0 dimana perkembangan dan persaingan industri dan teknologi sangat terlihat cepat dan banyak. Peningkatan pelayanan jasa ini sangatlah tergantung dengan sumber daya manusia yang berkualitas yang ada pada perusahaan. Sumber daya manusia atau karyawan yang merupakan aset berharga bagi perusahaan harus dikelolah dengan baik agar dapat memberikan kontribusi yang optimal. Salah satu hal yang harus menjadi perhatian utama perusahaan adalah dengan memperhatikan kepuasan kerja para karyawannya dengan tujuan agar karyawan dalam bekerja dapat merasa nyaman dan dihargai sehingga dengan parasaan tersebut maka 
karyawan dapat bersikap fokus mencapai tujuan yang ditetapkan perusahaan. Menurut (Robbins, 2008) kepuasan kerja sebagai perasaan positif seseorang atas pekerjaannya yang diperoleh dari suatu evaluasi terhadap karakteristik kepuasan itu sendiri.

Perhatian terhadap kepuasan kerja ini menjadi sangat genting dimana saat penelitian ini dilakukan saat dimana sedang terjadi pandemic covid-19 yang menyebabkan beberapa perusahaan menjalankan beberapa kebijakan yang selama ini belum pernah dijalankan. Salah satu kebijakan yang dijalankan PT. Kereta Api Indonesia (Persero) Divisi Regional III Palembang adalah adanya pembatasan sosial di lingkungan perusahaan. hal ini dilakukan sesuai dengan arahan presiden yang diberitakan dalam kompasdia (Vincentius Gitiyarko, 2020) yang mengatakan bahwa adanya seruan presiden agar masyarakat melakukan pembatasan sosial (sosial distancing) dengan menjalankan berbagai kegiatan dari rumah, mulai dari sekolah dirumah, bekerja dirumah dan ibadah dirumah sebagai bentuk upaya pencegahan menularan covid-19. Kebijakan ini menyebabkan karyawan harus bekerja lebih keras dalam menyelesaikan pekerjaannya walau dari rumah. Selain itu ketika mereka harus bekerja dikantor ada ketakutan dan kekhawatiran akibat dari mudahnya wabah pandemic covid-19 ini menyebar. Bentuk ketakutan dan kekhawatiran ini menjadi stress secara psikologis yang menjadi penghambat bagi perusahaan untuk menciptakan kepuasan kerja bagi karyawan. Sesuai dengan teori (Robbins, 2008), bahwa salah satu dampak stres secara psikologis dapat menurunkan kepuasan kerja karyawan.

Rasa kekhawatiran dimasa pandemic ini berdampak pada adanya keinginan karyawan untuk mencari keamanan dan keselamatan menjaga kesehatan diri. Hal ini jika dibiarkan oleh perusahaan maka akan menimbulkan keinginan niat keluar dari perusahaan yang sering disebut turnover intention. Apabila niat ini menjadi kenyataan dan karyawan benar keluar maka ini akan merugikan perusahaan. seperti yang dikatakan Carmeli dan Weisberg dalam (Suhanto, 2009) adanya karyawan yang keluar dari organisasi memerlukan biaya yang besar dalam bentuk kerugian yang besar akan tenaga ahli yang mungkin juga memindahkan pengetahuan spesifik perusahaan kepada pesaing. Untuk itu maka PT. Kereta Api Indonesia (Persero) Divisi Regional III Palembang perlu mengantisipasi adanya turnover intention dilingkungannya.

Kebijakan dari kerja dilakukan dirumah ini menyebabkan beberapa pekerjaan PT. Kereta Api Indonesia (Persero) Divisi Regional III Palembang memanfaatkan teknologi informasi. Karyawan harus dapat memahami penggunaan aplikasi dalam mengerjakan beberapa laporan pekerjaan mereka dari jarak jauh tanpa harus berada dikantor. Dengan adanya aplikasi yang baru diterapkan adaptasi penggunaan atau pengoperasionalan karyawan perlu diketahui oleh perusahaan. ini dianggap penting karena dengan dianggap mampunya karyawan teknologi informasi ini maka hambatan pelaksanaan kerja dari rumah dapat diatasi.

Penelitian Menurut (Wilson Lisan, 2016) melakukan penelitian dengan judul analisis pengaruh turnover karyawan, motivasi,dan pengayaan pekerjaan terhadap kepuasan kerja karyawan pada PT Enseval Putera Megatrading Tbk Manado. Hasil penelitiannya menunjukkan bahwa turnover karyawan, motivasi dan pengayaan pekerjaan secara simultan berpengaruh signifikan terhadap kepuasan kerja karyawan PT Enseval Putera Megatrading Tbk. Sedangkan secara parsial turnover dan motivasi berpengaruh signifikan terhadap kepuasan kerja karyawan dan pengayaan pekerjaan tidak berpengaruh signifikan terhadap kepuasan kerja karyawan. Penelitian (Ayu, 2017) dengan judul pengaruh teknologi informasi terhadap kepuasan kerja karyawan (Studi kasus pada PT. POS Indonesia (Persero) Surakarta), mengatakan bahwa secara bersama-sama bahwa teknologi informasi berpengaruh positif dan 
signifikan terhadap kepuasan kerja karyawan pada PT. Pos Indonesia (Persero) Surakarta.

Berdasarkan latar belakang diatas maka penelitian yang dilakukan memiliki tujuan untuk mengetahui pengaruh turnover intention dan teknologi informasi terhadap kepuasan kerja pada masa pandemi Covid-19 sehingga informasi yang didapat dari penelitian ini akan dapat dijadikan kesiapan keputusan dan kebijakan bagi PT. Kereta Api Indonesia (Persero) Divisi Regional III Palembang menghadapi karyawan disituasi pandemic saat ini dan kedepan dalam menyambut era new normal.

\section{Kajian Pustaka}

\subsection{Kepuasan Kerja}

Menurut (Robbins, 2008) menyatakan, bahwa kepuasan kerja adalah suatu sikap umum terhadap pekerjaan seseorang, selisih antara banyaknya ganjaran yang diterima seorang pekerja dan banyaknya ganjaran yang mereka yakini seharusnya mereka terima.

Menurut Herzberg (2008 : 55) berpendapat ada empat faktor yang mempengaruhi kepuasan kerja seseorang, faktor- faktor dalam kepuasan kerja yaitu: pertama, Faktor psikologik, berhubungan dengan kejiwaan karyawan yang meliputi minat, ketentraman dalam bekerja, sikap terhadap kerja, bakat dan keterampilan. Kedua, Faktor sosial, berhubungan dengan interaksi sosial yang meliputi interaksi sesama karyawan, interaksi dengan atasan, interaksi dengan karyawan yang berbeda jenis pekerjaannya. Ketiga, Faktor fisik, berhubungan dengan kondisi fisik lingkungan kerja dan kondisi fisik karyawan yang meliputi jenis pekerjaan, pengaturan waktu dan waktu istirahat, perlengkapan kerja, keadaan ruangan, suhu, penerangan, pertukaran udara dan kondisi, kesehatan karyawan, umur dan sebagainya. Keempat, Faktor finansial, berhubungan dengan jaminan serta kesejahteraan karyawan yang meliputi system dan besarnya gaji, jaminan sosial, barbagai tunjangan/ fasilitas yang diberikan, promosi dan sebagainya.

Sedangkan Ketidakpuasan karyawan menurut (Robbins, 2003) dapat diungkapkan dalam sejumlah cara atau dimensi sebagai berikut : pertama, Keluar, prilaku diarahkan ke meninggalkan organisasi, yang meliputi mencari posisi baru sekaligus mengundurkan diri. Kedua, Suara, secara aktif dan konstruktif berupaya memperbaiki kondisi, yang meliputi menyarankan perbaikan, mendiskusikan masalah dengan atasan, dan sebagian bentuk kegiatan perserikatan. Ketiga, Kesetiaan, secara pasif namun optimis menunggu perbaikan kondisi, yang meliputi membela organisasi dan kritikan eksternal dan mempercayai organisasi dan manajemennya untuk "melakukan hal yang benar." Dan keempat, Pengabaian, secara pasif membiarkan keadaan memburuk, yang meliputi keabsenan atau keterlambatan kronis, penurunan usaha, dan peningkatan tingkat kesalahan.

Menurut (Sudaryo, 2018) indikator kepuasan kerja terdiri atas: pertama, Kemangkiran, Pegawai yang tinggi tingkat kepuasan kerjanya akan rendah tingkat kemangkirannya, dan sebaliknya. Kedua, Keinginan Pindah, tidak dapat disangkal bahwa salah satu faktor penyebab timbulnya keinginan pindah kerja adalah ketidakpuasan ditempat bekerja sekarang. Ketiga, Kinerja Karyawan, merupakan hasil kerja secara kualitas dan kuantitas yang dicapai oleh seseorang karyawan dalam melakukan kemampuan melaksanakan tugas-tugas sesuai dengan tanggung jawab yang diberikan oleh atasan kepadanya. Keempat, Rekan Kerja, yaitu teman-teman kepada siapa seseorang senantiasa berinteraksi dalam pelaksanaan pekerjaan. Kelima, Kenyamanan Kerja Karyawan, karyawan cenderung lebih senang dengan adanya kondisi lingkungan kantor atau tempat kerja yang baik dan nyaman, sehingga efesiensi kerja suatu organisasi dapat tercapai dengan baik. 


\subsection{Turnover intention}

Menurut Senada Lee, dalam (Kartono, 2018) menjelaskan bahwa turnover intention merupakan suatu persepsi subjektif dari anggota organisasi untuk berhenti dari pekerjaannya saat ini dengan tujuan untuk mencari kesempatan lain.

Menurut Kuria et al, dalam (Kartono, 2018)menjelaskan bahwa ada dua faktor penyebab turnover intention, diantaranya yaitu: Faktor internal, yang dapat menjadi penyebab turnover intetion adalah ketidakpuasan kerja, kondisi lingkungan yang kurang kondusif, jam kerja yang panjang dengan pembayaran minimum dan program pelatihan yang buruk. Sedangkan faktor eksternal, yang mendorong kemunculan tujuan turnover intention adalah ekonomi negara, upah lebih baik ditempat lain, kekuatan ekonomi lokal dan regional dan tingkat pengangguran yang rendah.

Menurut Lum et al, dalam (Kuncoro, 2012) menyatakan bahwa indikator turnover intention yaitu: Intention to quit (niat untuk keluar), Job search (pencarian pekerjaan) dan Thinking of quit (memikirkan keluar)

\subsection{Teknologi Informasi}

Menurut Haag \& Keen dalam (Tata Sutabri, 2013) mengatakan bahwa teknologi informasi adalah seperangkat alat yang membantu anda bekerja dengan informasi dan melaksanakan tugas- tugas yang berhubungan dengan pemerosesan informasi.

Menurut Thompson, 1991 dalam (Rahmawati, 2008) faktor- faktor yang mempengaruhi teknologi informasi adalah sebagai berikut: faktor sosial, perasaan, kompleksitas, kesesuaian tugas, konsekuensi jangka panjang, kondisi yang memfasilitasi pemanfaatan teknologi informasi.

Menurut (Davis, 1986) dalam (Jogiyanto, 2007) indikator untuk membentuk konstruk tersebut yaitu: mudah dipelajari, terkendali, jelas dan dapat dimengerti, fleksibel, menjadi terampil, mudah untuk digunakan.

\section{Metode Penelitian}

Jenis penelitian yang digunakan dalam penelitian ini adalah berjenis penelitian asosiatif. Menurut Menurut (Diah Isnaini, 2019) jenis penelitian ditinjau dari tingkat eksplanasinya ada tiga macam, yaitu deskriptif, asosiatif, dan kompratif. Jenis penelitian yang digunakan dalam penelitian ini adalah penelitian asosiatif yaitu untuk mengetahui pengaruh turnover intention dan teknologi informasi terhadap kepuasan kerja.

Karyawan PT. Kereta Api Indonesia (Persero) Divisi Regional III Palembang 116 orang dijadikan sebagai populasi penelitian namun yang dijadikan sebagai sampel sebanyak 90 orang responden dengan menggunakan teknik Sampling Probability Sampling dan metode sampling yang digunakan adalah Proporionate Stratified Random Sampling. Data yang digunakan dalam penelitian ini adalah data primer.

Metode analisis yang digunakan dalam penelitian ini adalah metode analisis regresi linier berganda, uji $\mathrm{F}$ dan uji t yang dianalisis dengan menggunakan program komputer (software) SPSS versi 25. Analisis ini digunakan untuk menilai secara bersama-sama dan partial atas pengaruh turnover intention dan teknologi informasi terhadap kepuasan kerja pada masa pandemi Covid-19 di PT. Kereta Api Indonesia (Persero) Divisi Regional III Palembang. Sebelum melakukan analisis regresi terlebih dahulu dilakukan uji instrument atas kuesioner yang akan disebar sebagai sumber data. Adapun uji instrument yang dilakukan adalah uji 
validitas dan uji reliabilitas.

Model analisis statistik digambarkan dalam bentuk diagram berikut ini:

Gambar 1. Model Analisis Penelitian

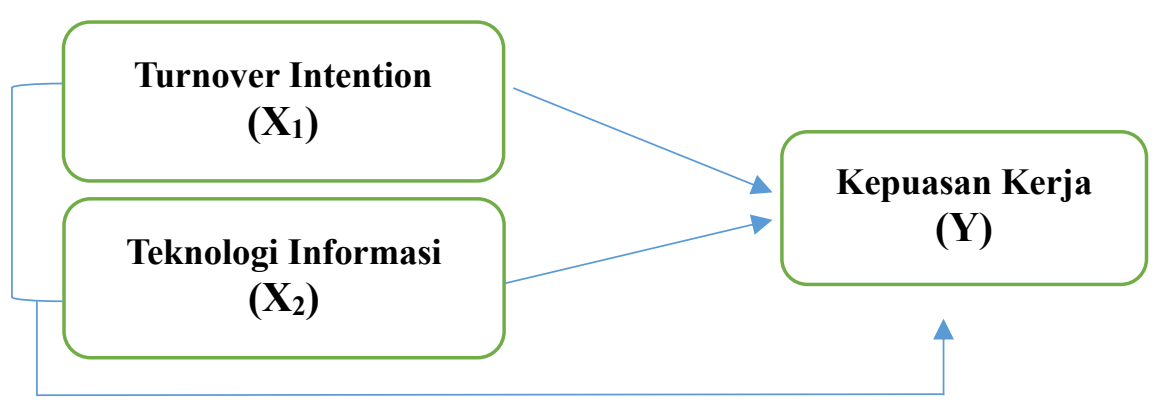

Sumber: Peneliti, 2020

Gambar ini menjelaskan tiga hipotesis dalam penelitian yang dilakukan:

1. Ada pengaruh turnover intention dan teknologi informasi terhadap kepuasan kerja pada masa Pandemi Covid-19 di PT. Kereta Api Indonesia (Persero) Divisi Regional III Palembang.

2. Ada pengaruh turnover intention terhadap kepuasan kerja pada masa Pandemi Covid-19 di PT. Kereta Api Indonesia (Persero) Divisi Regional III Palembang.

3. Ada pengaruh teknologi informasi tehadap kepuasan kerja pada masa pandemi Covid-19 di PT. Kereta Api Indonesia (Persero) Divisi Regional III Palembang.

Persamaan Regresi Linear Berganda:

$\mathbf{Y}=\mathbf{a}+\mathbf{b}_{1} \mathbf{X}_{1}+\mathbf{b}_{2} \mathbf{X}_{2}+\mathbf{e}$

Dimana :

$\mathrm{Y}=$ Kepuasan Kerja

$\mathrm{a} \quad=$ Konstanta

$\mathrm{b}_{1}=$ Koefisen Regresi Variabel Turnover intention

$\mathrm{X}_{1}=$ Turnover intention

$\mathrm{b}_{2}=$ Koefisen Regresi Variabel Kepuasan Kerja

$\mathrm{X}_{2}=$ Kepuasan Kerja

$\mathrm{e} \quad=$ error

\section{Hasil Penelitian dan Pembahasan}

\subsection{Hasil Penelitian}

\subsubsection{Uji Instrumen}

Dalam penelitian ini uji instrumen digunakan untuk menilai keabsahan dari butir-butir pernyataan setiap indikator variabel sehingga dapat memastikan bahwa butir pernyataan tersebut dinyatakan layak digunakan dan dapat dinilai dalam kelanjutan proses analisis penelitian. Uji instrumen dilakukan pada 12 butir pernyataan disebar kepada 30 orang responden. Berdasarkan hasil uji validitas secara keseluruhan ítem pada setiap indikator yang digunakan pada setiap butir pernyataan dalam kuesioner dinyatakan valid, hal ini 
dikarenakan nilai $r_{\text {hitung }}$ pada semua butir pernyataan dinyatakan lebih besar dari $r_{\text {tabel }}$ yang nilainya sebesar 0,361. Kemudian berdasarkan hasil uji reliabilitas diketahui bahwa keseluruhan indikator yang digunakan pada setiap butir pernyataan dalam penelitian ini dikatakan reliabel, karena keseluruhan indikator yang digunakan memiliki nilai lebih dari 0,6 . Disimpulkan bahwa semua butir pernyataan dalam kuesioner digunakan dalam analisis data penelitian.

\subsubsection{Hasil Regresi Linier Berganda}

Tabel 1. Regresi Linier Berganda

\begin{tabular}{llccc}
\hline Model & & Unstandardized Coefficients & $\begin{array}{c}\text { Standardized } \\
\text { Coefficients } \\
\text { Beta }\end{array}$ \\
\hline 1 & (Constant) & B & Std. Error & \\
& Turnover intention & 1.125 & .834 & .518 \\
& Teknologi Informasi & .562 & .155 & .364 \\
\hline
\end{tabular}

Sumber: Berdasarkan hasil perhitungan SPSS, 2020

Dari hasil tersebut dapat dijabarkan anallisis regresi linier berganda sebagai berikut:

$Y=1,125+0,562 X_{1}+0,386 X_{2}$

Dari analisis regresi linier berganda tersebut dapat dinyatakan empat kesimpulan. Pertama, nilai konstanta sebesar 1,125 berbentuk positif, dapat diartikan jika variabel turnover intention dan teknologi informasi tidak ada atau bernilai 0 (nol), maka nilai kepuasan kerja ada sebesar 1,125. Kedua, nilai koefisien turnover intention sebesar 0,562 berbentuk positif dapat menjelaskan bahwa adanya pengaruh antara turnover intention dengan kepuasan kerja. ketiga, nilai koefisien teknologi informasi sebesar 0,386 berbentuk positif dapat menjelaskan bahwa adanya pengaruh antara teknologi informasi dengan kepuasan kerja. Dan keempat, dari dua variabel independen yang diteliti yaitu turnover intention dan teknologi informasi maka dapat dilihat bahwa turnover intention pengaruhnya lebih besar jika dibandingkan teknologi informasi.

\subsubsection{Uji Hipotesis Secara Bersama-Sama (Uji F/Simultan)}

Tabel 2. Hasil Hipotesis Secara Bersama-Sama/ Simultan (Uji f) ANOVA ${ }^{b}$

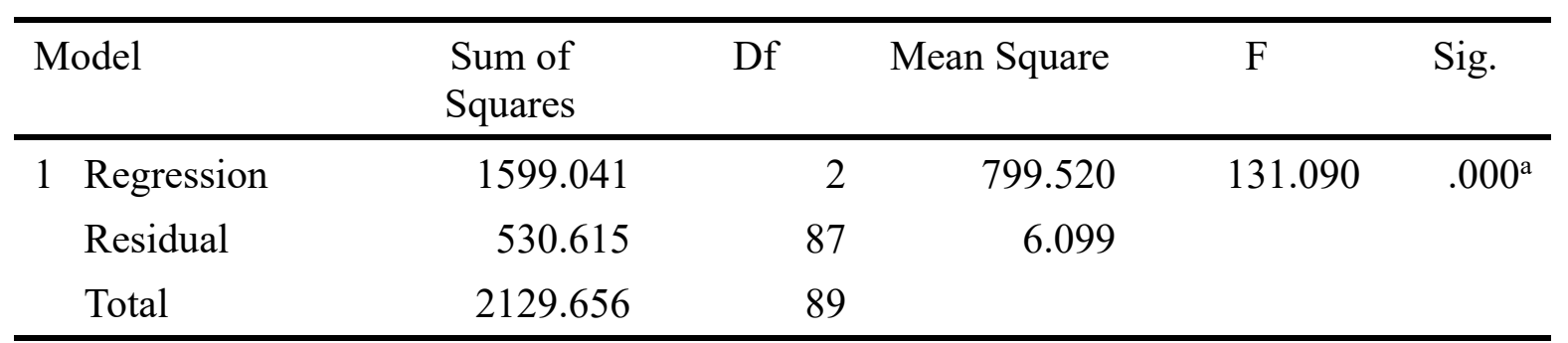

Berdasarkan tabel hasil uji hipotesis secara bersama-sama/ simultan, dapat diartikan bahwa turnover intention dan teknologi informasi berpengaruh terhadap kepuasan kerja yang

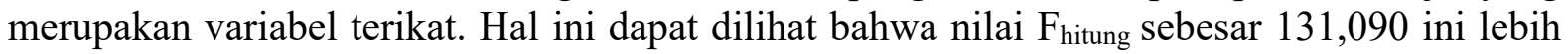
besar jika dibandingkan dengan nilai $\mathrm{F}_{\text {tabel }}$ sebesar 3,10. Kemudian diperkuat dengan tingkat sig. F sebesar 0,000 yang menjelaskan bahwa nilai ini lebih kecil dari ketetapan tingkat kesalahan sebesar 5\% atau 0,05, maka ini diartikan bahwa Ho ditolak, artinya ada pengaruh 
signifikan turnover intention dan teknologi informasi terhadap kepuasan kerja pada masa pandemi Covid-19 di PT. Kereta Api Indonesia (Persero) Divisi Regional III Palembang.

4.1.4.Uji Hipotesis Secara Individual / Uji t (Parsial)

Tabel 3. Hasil Hipotesis Secara Individual/Parsial (Uji t)

\begin{tabular}{llccccc}
\hline \multirow{2}{*}{ Model } & \multicolumn{2}{c}{$\begin{array}{c}\text { Unstandardized } \\
\text { Coefficients }\end{array}$} & $\begin{array}{c}\text { Standardized } \\
\text { Coefficients }\end{array}$ & T & Sig. \\
\cline { 3 - 5 } & \multicolumn{2}{c}{ B } & $\begin{array}{c}\text { Std. } \\
\text { Error }\end{array}$ & Beta & & \\
\hline 1 & & & & & \\
& (Constant) & 1.125 & .834 & & 1.350 & .180 \\
& Turnover intention & .562 & .155 & .518 & 3.630 & .000 \\
& Teknologi Informasi & .386 & .151 & .364 & 2.555 & .012 \\
\hline
\end{tabular}

Berdasarkan tabel hasil uji hipotesis secara individual/ parsial, dapat diartikan bahwa terdapat pengaruh antara turnover intention atau teknologi informasi secara parsial terhadap kepuasan kerja. Hal ini dapat dilihat dan dijelaskan dari hasil perbandingan nilai $t_{\text {hitung }}$ lebih besar dari nilai t tabel yang nilainya sebesar 1,662.

Pertama, dari tabel di dapat bahwa $t_{\text {hitung }}$ untuk turnover intention nilainya sebesar 3,630 nilai ini lebih besar dari nilai tabel sebesar 1,662. Diperkuat dengan tingkat sig. $t$ sebesar 0,000 yang menjelaskan bahwa nilai ini lebih kecil dari ketetapan tingkat kesalahan sebesar 5\% atau 0,05, maka Ho ditolak, artinya ada pengaruh signifikan turnover intention terhadap kepuasan kerja pada masa pandemi Covid-19 di PT. Kereta Api Indonesia (Persero) Divisi Regional III Palembang.

Kedua, dari tabel di dapat bahwa thitung untuk teknologi informasi nilainya sebesar 2,555 dimana nilai ini lebih besar dari nilai $t_{\text {tabel }}$ sebesar 1, 662. Diperkuat dengan tingkat sig. $t$ sebesar 0,001 yang menjelaskan bahwa nilai ini lebih kecil dari ketetapan tingkat kesalahan sebesar 5\% atau 0,05 maka Ho ditolak, artinya ada pengaruh signifikan teknologi informasi terhadap kepuasan kerja pada masa pandemi Covid-19 di PT. Kereta Api Indonesia (Persero) Divisi Regional III Palembang.

\subsubsection{Uji Koefisien Determinasi $\left(\mathrm{R}^{2}\right)$}

Hasil analisis ini dapat dilihat pada tabel berikut ini :

Tabel 6. Koefisien Determinasi Model Summary ${ }^{\mathrm{b}}$

\begin{tabular}{ccccc}
\hline Model & $\mathrm{R}$ & R Square & Adjusted R Square & $\begin{array}{c}\text { Std. Error of the } \\
\text { Estimate }\end{array}$ \\
\hline $.867^{\mathrm{a}}$ & .751 & .745 & 2.470 \\
\hline
\end{tabular}

Berdasarkan tabel di atas, diperoleh nilai Adjusted R Square (koefisien determinasi) sebesar 0,745 artinya variabel turnover intention dan teknologi informasi memiliki konstribusi terhadap naik turunnya kepuasan kerja sebesar 74,5\%. Sedangkan sisanya sebesar $25,5 \%$ dijelaskan oleh variabel-variabel lain yang tidak termasuk dalam penelitian ini. 


\subsection{Pembahasan}

Hasil analisis regresi linier berganda, diketahui adanya pengaruh yang positif dari turnover intention dan teknologi informasi terhadap kepuasan kerja pada masa pandemi covid-19 di PT. Kereta Api Indonesia (Persero) Divisi Regional III Palembang. Hasil uji hipotesis secara bersama-sama menunjukkan bahwa ada pengaruh yang signifikan turnover intention dan teknologi informasi terhadap kepuasan kerja pada masa pandemi covid-19 di PT. Kereta Api Indonesia (Persero) Divisi Regional III Palembang. Hasil uji hipotesis secara parsial, menunjukan ada pengaruh yang signifikan turnover intention terhadap kepuasan kerja pada masa pandemi covid-19 di PT. Kereta Api Indonesia (Persero) Divisi Regional III Palembang. Dan ada pengaruh yang signifikan teknologi informasi terhadap kepuasan kerja pada masa pandemi covid-19 di PT. Kereta Api Indonesia (Persero) Divisi Regional III Palembang. Kemudian pengaruh turnover intention dan teknologi informasi terhadap kepuasan kerja ini diperkuat dari hasil uji determinasi bahwa antara turnover intention dan teknologi informasi saling berkaitan dalam berkonstribusi sebesar 74,5\% mempengaruhi kepuasan kerja pada masa pandemi Covid-19 di PT. Kereta Api Indonesia Divisi Regional III Palembang. Apabila dilihat dari hasil analisis regresi berganda dan uji parsial pengaruh diantara kedua variabel yang diteliti terhadap kepuasan kerja dikatakan bahwa turnover intention berpengaruh lebih besar apabila dibandingkan dengan variabel teknologi informasi.

Penjelasan dari hasil-hasil tersebut sejalan dengan teori yang dinyatakan oleh (Sudaryo, 2018), menjelaskan bahwa indikator yang mempengaruhi kepuasan kerja adalah kemangkiran dan keinginan pindah, kemangkiran dan keinginan untuk pindah berpengaruh terhadap kepuasan kerja dimana jika karyawan melakukan kemangkiran dan berkeinginan untuk pindah maka tingkat kepuasan kerja tersebut belum tercapai secara maksimal, Thompson dalam (Rahmawati, 2008), faktor yang mempengaruhi teknologi informasi terhadap kepuasan kerja adalah kesesuaian tugas, bahwa kesiapan tugas berpengaruh terhadap kepuasan kerja dimana jika kesesuaian tugas dengan teknologi informasi secara lebih spesifik menunjukkan hubungan pemanfaatan teknologi informasi dengan kebutuhan tugas yang berlebihan maka kenyamanan dan kepuasan kerja karyawan tidak akan tercapai dengan maksimal.

Hasil ini juga didukung penelitian sebelumnya yang dilakukan oleh (Wilson Lisan, 2016) dengan hasil yang membuktikan bahwa turnover intention berpengaruh positif terhadap kepuasan kerja turnover turnover intention karyawan berpengaruh postif terhadap kepuasan kerja karyawan di PT. Enseval Megatrading Tbk Manado. Maka hasil penelitian tersebut sejalan dengan penelitian ini, dengan hasil yang sama-sama menunjukkan adanya pengaruh turnover intention terhadap kepuasan kerja karyawan. Kemudian sejalan dengan Penelitian sebelumnya dari (Ayu, 2017), dengan hasil yang membuktikan bahwa teknologi informasi berpengaruh positif dan signifikan terhadap kepuasan kerja karyawan pada PT. Pos Indonesia (Persero) Surakarta. Maka hasil yang sama-sama menunjukkan adanya pengaruh teknologi informasi terhadap kepuasan kerja karyawan.

Pengaruh turnover intention terhadap kepuasan kerja, memberikan gambaran bahwa dengan adanya turnover intention akan dapat memberi konstribusi dalam meningkatkan kepuasan kerja. Melalui turnover intention bagi karyawan terlebih pada kondisi pandemi covid-19 yang terjadi saat ini. Turnover intention yang dilakukan berupa menciptakan kondisi perkerjaan yang nyaman dan menciptakan rasa tenang, memberikan fasilitas kerja yang memadai, dan memberikan pengakuan atas pekerjaan yang dilakukan karyawan bahwa karyawan telah melakukan pekerjaan dengan baik. Sedangkan Pengaruh teknologi informasi terhadap kepuasan kerja, memberikan gambaran bahwa teknologi informasi memiliki konstribusi dalam meningkatkan kepuasan kerja. 


\section{Kesimpulan dan saran}

Dari hasil penelitian yang dilakukan pada PT. Kereta Api Indonesia (Persero) Divisi Regional III Palembang beberapa simpulan yang dibuat mengenai kepuasan kerja, yaitu:

1. Ada pengaruh signifikan turnover intention dan teknologi informasi terhadap kepuasan kerja pada masa pandemi covid-19 di PT. Kereta Api Indonesia (Persero) Divisi Regional III Palembang.

2. Ada pengaruh signifikan turnover intention terhadap kepuasan kerja pada masa pandemi covid-19 di PT. Kereta Api Indonesia (Persero) Divisi Regional III Palembang.

3. Ada pengaruh signifikan teknologi informasi terhadap kepuasan kerja pada masa pandemi covid-19 di PT. Kereta Api Indonesia (Persero) Divisi Regional III Palembang.

Dari hasil penelitian yang dapat dijadikan sebagai masukan bagi PT. Kereta Api Indonesia (Persero) Divisi Regional III Palembang, adalah:

1. Perusahaan tetap menjaga dan meningkatkan perhatian terkait dengan terciptanya kepuasan kerja karyawan, seperti terus meningkatkan fasilitas teknologi informasi dan kelengkapan sarana pekerjaan serta mengadakan pendampingan pelatihan untuk bisa menyeimbangi tersedianya fasilitas teknologi informasi tersebut.

2. Perusahaan perlu menyiapkan kebijakan-kebijakan guna mencegah turnover intention yang sering terjadi pada karyawan ketika karyawan merasakan ketidaknyamanan terhadap situasi tertentu.

3. Perusahaan juga perlu memperhatikan hal hal yang mendorong penggunaan teknologi informasi, dengan penerapan sistem pekerjaan baru yang akan menjadikan pekerjaan lebih efektif dan efesien.

\section{Referensi}

Ayu, M. (2017). Pengaruh Penggunaan Teknologi InformasiTerhadap Kepuasan Kerja Karyawan (Studi Kasus pada PT. Pos Indonesia (Persero) Surakarta) Disusun. Doctoral Dissertation, Universitas Muhammadiyah Surakarta.

Diah Isnaini, D. (2019). Metodelogi Penelitian Bisnis. noerfikri.

Jogiyanto, H. (2007). Sistem Informasi Keperilakuan. Andi.

Kartono. (2018). Personality,Employee Engagement, Emotional Intellegence, Job Burnout Pendekatan dalam Melihat Turnover intention. Deepublish.

Kuncoro, A. W. (2012). PENGARUH SISTEM REMUNERASI, KEPUASAN KERJA, KOMITMEN ORGANISASIONAL INTENTION, TERHADAP TURNOVER. https://journal.budiluhur.ac.id/index.php/ema/article/view/282/228

Rahmawati, D. (2008). ANALISIS FAKTOR-FAKTOR YANG BERPENGARUH TERHADAP PEMANFAATAN TEKNOLOGI INFORMASI. Jurnal Ekonomi \& Pendidikan, Volume 5 Nomor 1. https://media.neliti.com/media/publications/17232-ID-analisis-faktorfaktor-yang-berpengaruh-terhadap-pemanfaatan-teknologi-informasi.pdf

Robbins, S. P. (2003). Prilaku Organisasi. Prentice-Hall.

Robbins, S. P. dan T. A. (2008). Perilaku Organisasi, Edisi 12 Buku 1. In Jakarta: Salemba Empat.

Sudaryo, Y. (2018). Manajemen Sumber Daya Manusia: Kompensasi Tidak Langsung dan Lingkungan Kerja Fisik. Penerbit Andi.

Suhanto, E. (2009). Pengaruh Stress Kerja dan Iklim Organisasi terhadap Turnover intention 
dengan Kepuasan Kerja sebagai Variabel Intervening (Studi di Bank Internasional Indonesia). Tesis. Magister Manajemen Pascasarjana. Universitas Diponegoro.Semarang.

Tata Sutabri, S. K. (2013). Pengantar Teknologi Informasi. In CV. ANDI OFFSET.

Vincentius Gitiyarko. (2020). Upaya dan Kebijakan Pemerintah Indonesia Menangani Pandemi Covid-19. Senin, 22 Juni 2020 19:50:43 WIB, 1-21. https://kompaspedia.kompas.id/baca/paparan-topik/upaya-dan-kebijakan-pemerintahindonesia-menangani-pandemi-covid-19

Wilson Lisan, J. S. G. S. (2016). ANALISIS PENGARUH TURNOVER KARYAWAN, MOTIVASI, DAN PENGAYAAN PEKERJAAN, TERHADAP KEPUASAN KERJA KARYAWAN PADA PT. ENSEVAL MEGATRADING TBK MANADO. JURNAL BERKALA ILMIAH EFISIENSI, 16(3). 